\title{
Saxitoxin $\delta^{15} \mathbf{N}$ as a species-specific tracer of the source of nitrogen used by the toxin-producing dinoflagellate Alexandrium tamarense
}

\author{
Christa B. Smith ${ }^{1,2, *}$, Deana L. Erdner ${ }^{1}$ \\ ${ }^{1}$ University of Texas, Marine Science Institute, 750 Channel View Drive, Port Aransas, Texas 78373, USA \\ ${ }^{2}$ Present address: University of Georgia, Marine Sciences Bldg 1030, Athens, Georgia 30602, USA
}

\begin{abstract}
Alexandrium tamarense Balech is a harmful, bloom-forming dinoflagellate which can produce saxitoxins (STXs), a suite of powerful neurotoxins that bioaccumulate up the food chain and can have severe economic and health impacts. Being nitrogen-rich, STX is ideal for studying the relationship between its producer and the nitrogen used for growth. In this study, we measured the $\delta^{15} \mathrm{~N}$ of medium nitrate, algal cells and toxin in batch cultures of A. tamarense. In nitrate-replete conditions, cells were $1.5 \%$ o depleted relative to the source, and STX was $1.5 \%$ depleted relative to the cells. In nitrogen-limiting cultures the isotopic difference between cells and STX changed as nitrate in the growth medium was depleted, indicating uncoupled toxin synthesis and cell growth under changing external nutrient conditions. Our results show that toxinspecific nitrogen stable isotope analysis may provide a tool that can help to identify the nitrogen sources supporting toxic Alexandrium blooms.
\end{abstract}

KEY WORDS: Alexandrium tamarense $\cdot \delta^{15} \mathrm{~N} \cdot$ Harmful algal blooms - Isotopic analysis · Saxitoxin $\cdot$ Stable nitrogen isotopes

\section{INTRODUCTION}

Harmful algal blooms (HABs) are episodes of increased algal biomass that can severely affect the environment and cause substantial economic losses in affected regions. Even at relatively low cell concentrations, toxins produced by some species of phytoplankton can bioaccumulate and affect higher trophic levels (Anderson et al. 2002, GEOHAB 2006). Recent temporal and spatial increases in the incidence of HABs are causing worldwide concern for both the environment and human health (Smayda 1990, Hallegraeff 1993). Nutrients play a key role in the growth and reproduction of phytoplankton, with availability and limitation resulting in various, and often adverse, effects on phytoplankton communities. For instance, anthropogenic nitrogen loading from sewage or agricultural activities can lead to anomalously high concentrations of nutrients and potentially fuel HABs in coastal areas (Smayda 1990, Paerl 1997). Although nutrient loadings have been linked to an increased incidence of HABs (Anderson et al. 2002, GEOHAB 2006), the relationship is still poorly understood. A better understanding of the relationship between nutrient supply and the initiation and termination of HABs is necessary in order to predict and mitigate the effects of these events.

Among the variety of toxin-poisoning syndromes linked to HABs, paralytic shellfish poisoning (PSP) is one of the most geographically widespread. It results from the ingestion of paralytic shellfish toxins (PSTs), a group of structurally-related, water-soluble neurotoxins that bioaccumulate as they are passed from producer to consumer (Wang 2008). PSTs, unlike most algal toxins, are perhydropurine alkaloids containing significant amounts of nitrogen. Individual 
PST congeners vary in their toxicities, and the suite of PSTs produced varies by species and strain. Saxitoxin ( $\mathrm{STX}_{i} \mathrm{C}_{10} \mathrm{H}_{17} \mathrm{~N}_{7} \mathrm{O}_{4}$ ) is the parent compound and one of the most toxic and well-studied of the PSTs that are produced by dinoflagellates. To date, 3 genera of dinoflagellates have been found to produce PSTs: Pyrodinium, Gymnodinium and Alexandrium (Shumway 1990). Of these, Alexandrium comprises over 24 globally distributed species and is the most common cause of PSP outbreaks worldwide (Scholin \& Anderson 1993).

Alexandrium growth and toxin production is affected by ambient physical and chemical conditions. PSTs are nitrogen-rich compounds, and both the form and quantity of the available nitrogen can affect the cellular content of toxins. Nitrogen limitation affects toxin production pathways before cellular division, and thus the cellular content of toxin decreases as cells continue to divide (Boyer et al. 1987, Anderson et al. 1990). The form of nitrogen also affects cellular dynamics, and HABs have been associated with high inputs of reduced nitrogen compounds (Leong et al. 2004).

Stable isotopes provide a way to investigate nutrient fluxes in ecological studies, especially trophic networks, and can be used to identify the source and cycling of materials through a system (Minagawa \& Wada 1984, Peterson \& Fry 1987, Gannes et al. 1998, McClelland \& Montoya 2002). Thus, stable isotopes could provide a useful tool for investigating nutrient sources involved in Alexandrium blooms and toxin production. For example, Hattenrath et al. (2010) found that the isotopic signature of particulate organic matter collected during a toxic $A$. fundyense bloom was similar to the isotopic signature of sewage-derived nitrogen. Because HAB species are part of a complex community, compound-specific tracers are required to separate out the nutrient response of specific $\mathrm{HAB}$ species from that of the plankton community as a whole. Cellular toxins, and in particular the nitrogen-rich PSTs, provide unique, compound-specific nitrogen tracers.

Understanding the relationship between nutrients and HABs requires knowledge of how nutrients move through a system. Compounds moving relatively unchanged through a system provide information on the source of those compounds, whereas those undergoing isotopic changes provide information on processing and trophic levels in the organism from which the compounds are isolated. PSTs can potentially be utilized as highly specific tracers of either the source or processing of nitrogen within the algal cell. Our objective in this study was to deter- mine whether the nitrogen isotopic signature of STX could serve as an indicator of the source of nitrogen used for growth and toxin production.

\section{MATERIALS AND METHODS}

\section{Algal cultures}

The toxin-producing dinoflagellate Alexandrium tamarense strain PW06 (Group I; Lilly et al. 2007) was obtained from the laboratory of D. Anderson at the Woods Hole Oceanographic Institution. This strain was chosen because it primarily produces the STX parent compound (94.4 mol\%) with only a minor contribution from the congener neoSTX (5.6 mol\%). Two experiments were conducted: (1) a pilot study using nitrate-replete batch cultures, and (2) a time-course study of replicate nitrogen-limiting batch cultures. Cells were cultured in pre-filtered (pore size $0.22 \mu \mathrm{m}$ ) seawater from the Gulf of Mexico amended with sterile $\mathrm{f} / 2$ nutrients excepting silicate $\left(883 \mu \mathrm{mol} \mathrm{l}^{-1}\right.$ nitrate, $36.2 \mu \mathrm{mol} \mathrm{l}^{-1}$ phosphate, trace metals and vitamins; Guillard 1975) in 201 carboys outfitted with air-in, air-out, and collection ports for aseptic removal of samples. Cultures were constantly and gently bubbled with HEPA-filtered air from a Tetra Whisper air pump and maintained at $15^{\circ} \mathrm{C}$, on a $12: 12 \mathrm{~h}$ light:dark cycle and with cool-white, fluorescent illumination of approx. $150 \mu \mathrm{mol}$ photons $\mathrm{m}^{-2} \mathrm{~s}^{-1}$.

Nitrate-replete cells were grown in a single 201 carboy in medium containing a starting nitrate concentration of $833 \mu \mathrm{mol} \mathrm{l}^{-1}$. Nitrate stock $\delta^{15} \mathrm{~N}$ was measured at $-7.0 \pm 0.1 \%$ o $(n=2)$. The experiment was started by inoculating the carboy to approx. 200 cells $\mathrm{ml}^{-1}$ with a mid-exponential phase culture of the same strain. Cells were sampled daily, preserved in Lugol's iodine, and counted on a Sedgwick-Rafter counting cell. Nitrate was periodically added to the culture $\left(88.3 \mu \mathrm{mol}\right.$ nitrate for every $200 \mathrm{cells} \mathrm{ml}^{-1}$ increase) to maintain a high and relatively constant concentration of nitrate. Cells were harvested postlog phase (in order to have sufficient cells for toxin purification) for isotopic analysis. Triplicate $15 \mathrm{ml}$ samples were used for analysis of the whole-cell nitrogen isotope and approx. 6 and 141 were used for analysis of the STX nitrogen isotope.

Nitrogen-limiting cultures were enriched to a starting concentration of $88.3 \mu \mathrm{mol} \mathrm{^{-1 }}$ nitrate (one-tenth of $\mathrm{f} / 2$ level) from a stock with a measured $\delta^{15} \mathrm{~N}$ of $-1.8 \pm 0.5 \%$ o $(n=3)$. Triplicate carboys $(A, B$ and $C)$ were initially inoculated with an identical volume of 
a mid- to late-exponential phase culture of the same strain, to a starting cell density of approx. 200 cells $\mathrm{ml}^{-1}$. The inoculum culture was grown on nitrate with a measured $\delta^{15} \mathrm{~N}$ of $-7.0 \%$. After inoculation, the remaining inoculum volume (approx. 2.5 l) was harvested for analysis of the Day 0 STX isotope. Cultures were monitored daily for cell counts and nitrate concentration. Duplicate samples were taken from 2 of the 3 carboys every other day for isotopic analysis, cycling $\mathrm{A} / \mathrm{C} \rightarrow \mathrm{A} / \mathrm{B} \rightarrow \mathrm{B} / \mathrm{C}$ until cultures were exhausted. The sampling schedule was chosen because large volumes were required from early and late cultures for STX and nitrate measurements, respectively. Alternating carboys allowed cultures to be followed over time until after the nitrate in the medium had been exhausted and culture growth had stopped. For the purification of STX, the volumes filtered over time were as follows: carboy (A) 8, 4, 2, 2 and 41 on Days 4, 6, 10, 12 and 16, respectively; carboy (B) 4, 2, 2, 2, 2 and 81 on Days 6, 8 12, 14, 18 and 20, respectively; carboy (C) 8, 2, 2, 2, 2 and 41 on days $4,6,8,10,14$ and 16 , respectively.

\section{Measurements of nitrate in the medium}

Medium samples $(15 \mathrm{ml})$ were filtered through $25 \mathrm{~mm}$, pre-combusted Whatman GF/F filters, and nitrate concentrations were measured according to Jones (1984), with modification. Briefly, spongy cadmium was prepared by placing a zinc stick into $20 \%$ w/v cadmium sulfate in Milli-Q water. The precipitated spongy cadmium was broken into 0.5 to $1.0 \mathrm{~g}$ pieces, acidified with $6 \mathrm{~mol} \mathrm{l}^{-1}$ hydrochloric acid and washed with Milli-Q water to reach pH 7.0. Each well of a $2.0 \mathrm{ml}$ deep-well microplate was prepared with 0.5 to $1.0 \mathrm{~g}$ of spongy cadmium, $100 \mu \mathrm{l} 0.7 \mathrm{~mol} \mathrm{l}^{-1} \mathrm{am}-$ monium chloride pH 8.5 and $1.0 \mathrm{ml}$ sample. After sealing, the microplate was incubated at room temperature in a horizontal shaker for $90 \mathrm{~min}$ at $150 \mathrm{rpm}$. Subsequently, $200 \mu$ l of each reaction was transferred to a $400 \mu \mathrm{l}, 96$-well plate, and $20 \mu \mathrm{l}$ each of prepared sulfanilamide $\left(2 \% \mathrm{w} / \mathrm{v}\right.$ in $\left.4 \mathrm{~mol} \mathrm{l}^{-1} \mathrm{HCl}\right)$ and $\mathrm{N}-1$ napthyl ethylene diamine (NED, $0.2 \% \mathrm{w} / \mathrm{v}$ in water) were added. The plate was covered immediately and incubated in the dark at room temperature for $60 \mathrm{~min}$. Color development was detected as absorbance at $543 \mathrm{~nm}$ using a SPECTRAmax 190 microplate reader.

Isotopic analysis of medium nitrate was conducted according to the ammonium diffusion method of Sigman et al. (1997). Diffusions were performed in $100 \mathrm{ml}$ volumes containing 0.0 to $10.0 \mu \mathrm{mol}$ of nitrogen. Magnesium oxide (0.003 $\mathrm{g} \mathrm{ml}^{-1}$ initial sample) was added to the sample in a beaker. All samples were boiled to eliminate ammonium in the medium and to break down labile dissolved organic nitrogen (DON). Volumes $>150 \mathrm{ml}$ were boiled down, with constant stirring, to just under $100 \mathrm{ml}$. Milli-Q water was added to volumes $<150 \mathrm{ml}$ before boiling. After boiling, samples were cooled and transferred to $250 \mathrm{ml}$ HDPE wide-neck square bottles. Sodium chloride $\left(0.05 \mathrm{~g} \mathrm{ml}^{-1}\right.$ final sample) was added to the standards, which were prepared in Milli-Q water. A diffusion packet, consisting of a pre-combusted and acidified GF/D filter sandwiched between 2 Teflon membrane filters, was placed into each bottle. Lastly, Devarda's alloy (0.0025 $\mathrm{g} \mathrm{ml}^{-1}$ final sample) was added to convert nitrate to ammonium during sample incubation. Bottles were immediately closed and placed in an incubator at $40^{\circ} \mathrm{C}$, with shaking at $\sim 100 \mathrm{rpm}$, for $1 \mathrm{wk}$. Following incubation, each diffusion packet was dipped into Milli-Q water and dried in a desiccator for at least $3 \mathrm{~d}$ or until isotopic analysis. Both experimental nitrate concentration measurements and diffusions were run concurrently with prepared nitrate standards.

\section{Saxitoxin purification}

Sample volumes were filtered through a $20 \mu \mathrm{m}$ mesh, and the retained cells were washed into $50 \mathrm{ml}$ centrifuge tubes, using sterile seawater, and then collected by centrifugation at $3000 \times g$ for $10 \mathrm{~min}$. The supernatant was decanted and the cells were resuspended in $10 \mathrm{ml}$ of $0.1 \mathrm{~mol} \mathrm{l}^{-1}$ acetic acid. Cell suspensions were sonicated 5 times, at 30 s intervals, over ice using a Branson Sonifier 250 at a constant output of $40 \mathrm{~W}$, followed by centrifugation at $3000 \times g$ for $10 \mathrm{~min}$. Using a rotary evaporator, cell extracts were evaporated to near dryness at $60^{\circ} \mathrm{C}$ and resuspended in $2 \mathrm{ml}$ of $0.1 \mathrm{~mol} \mathrm{l}^{-1}$ acetic acid.

Chromatographic purification was adapted from Laycock et al. (1994) using $7 \mathrm{~mm}$ ID $\times 15 \mathrm{~cm}$ length columns packed to a depth of $13.5 \mathrm{~cm}$. All samples were eluted in $1.5 \mathrm{ml}$ fractions at a rate of 0.14 to $0.35 \mathrm{ml} \mathrm{min}^{-1}$. Purification was performed using both size-exclusion and ion-exchange resins. Samples were first eluted in $0.1 \mathrm{~mol} \mathrm{l}^{-1}$ acetic acid through Bio-Gel P2 (Bio-Rad, Hercules) resin reconstituted in $0.1 \mathrm{~mol} \mathrm{l}^{-1}$ acetic acid. Partially purified toxin samples were dried and resuspended in 200 to $400 \mu \mathrm{l}$ of $0.2 \mathrm{~mol} \mathrm{l}^{-1}$ sodium phosphate buffer $\mathrm{pH}$ 6.8. These samples were eluted using a 0.0 to $3.0 \mathrm{~mol}^{-1}$ acetic acid gradient through Bio-Rex-70 resin (Bio-Rad, Hercules) reconstituted with $1 \mathrm{~mol} \mathrm{l}^{-1}$ hydrochloric 
acid and stabilized with Milli-Q water. Resins were prepared fresh for each sample.

STX-positive fractions were determined in comparison to a positive control (National Research Council of Canada (NRC), CRM-STX-e, lot \# 20060419STX) using thin-layer chromatography (TLC) according to Buckley et al. (1976), on precoated silica gel 60 plates (Merck). Briefly, sample aliquots were spotted onto the plate and developed for $3 \mathrm{~h}$ in a pyridine:ethyl acetate:water:acetic acid (75:25:30:15) solvent system. After development, plates were dried at $60^{\circ} \mathrm{C}$, sprayed evenly with $1 \% \mathrm{H}_{2} \mathrm{O}_{2}$, heated at $100^{\circ} \mathrm{C}$ for $30 \mathrm{~min}$ and then detected under long-wave UV (366 nm). The detection limit of this TLC method is $0.04 \mu \mathrm{g}$ STX (Buckley et al. 1976). While TLC does not completely separate all STX congeners, prior chromatographic separations and comparison to an STX standard allowed qualitative identification of the purified compound as STX. The STX yield from positive fractions was calculated using mass spectrometry nitrogen quantification (see 'Isotopic measurements') together with number of cells extracted.

\section{Isotopic measurements}

Whole-cell samples ( 3 to 4 million cells) were collected on $25 \mathrm{~mm}$ pre-combusted Whatman GF/F filters, dried overnight at $60^{\circ} \mathrm{C}$, and wrapped in tin capsules for isotopic analysis. STX-positive fractions were transferred into tin capsules and placed at $60^{\circ} \mathrm{C}$ until just dry and then wrapped for isotopic analysis. Dried diffusion packets were dissected, and the inner $1 \mathrm{~cm}$, pre-combusted Whatman GF/D (\#1823010) filters were wrapped in tin capsules just prior to isotopic analysis. All isotopic measurements were done using a Finnigan Mat Delta Plus isotope ratio mass spectrometer coupled to a Carlo Erba NC 2500 elemental analyzer (University of Texas at Austin, Marine Science Institute). The detection limit for greatest accuracy was $0.5 \mu \mathrm{mol}$ of nitrogen and $4 \mu \mathrm{mol}$ of carbon. Isotope values are reported with respect to established standards: $\delta^{15} \mathrm{~N}$ of air.

\section{RESULTS}

\section{Toxin purification}

Of the STX-positive fractions, $10 \%$ were sent with an STX NRC standard to the M. D. Anderson Center (University of Texas at Austin) where the purity of the STX fractions was verified by liquid chromatog- raphy using quadrapole ion-trap mass spectrometry with electrospray ionization following the method of Jaime et al. (2001). These samples were scanned over a mass-to-charge ratio $(\mathrm{m} / \mathrm{z})$ of 80 to 320 . Experimental samples contained a single peak at $\mathrm{m} / \mathrm{z}$ of 300.3 , consistent with both the expected STX value of $\mathrm{m} / \mathrm{z}$ 300.1 and the NRC standard.

Nitrate-replete cells yielded $22.8 \mathrm{fmol} \mathrm{STX} \mathrm{cell}{ }^{-1}$. Nitrogen-limiting cultures between Days 0 and 18, except on Day 4, yielded between 39.6 and $70.5 \mathrm{fmol}$ $\mathrm{STX} \mathrm{cell}^{-1}$ (Fig. 1). On day 4, the STX yield increased to a high of $207 \mathrm{fmol} \mathrm{cell}^{-1}$.

\section{Nitrate-replete culture}

Under nitrate-replete conditions, cells reached a peak density of 2235 cells $\mathrm{ml}^{-1}$ on Day 27 with an exponential growth rate $(\mu)$ of $0.2 \mathrm{~d}^{-1}$ between Days 10 and 23 (data not shown). Cells were harvested on Day 31 , at a density of 2050 cells ml$^{-1}$. Isotopic values from nitrate-replete culture showed a $1.5 \%$ decrease in $\delta^{15} \mathrm{~N}$ between medium nitrate and whole-cell nitrogen, and between whole-cell nitrogen and STX nitrogen (Table 1).

\section{Nitrogen-limiting cultures}

Nitrogen-limiting time-course cultures reached an average peak density of 4314 cells $\mathrm{ml}^{-1}$ on Day 16 (Fig. 2), with a $\mu$ of $0.4 \mathrm{~d}^{-1}$ over Days 3 to 13. Medium

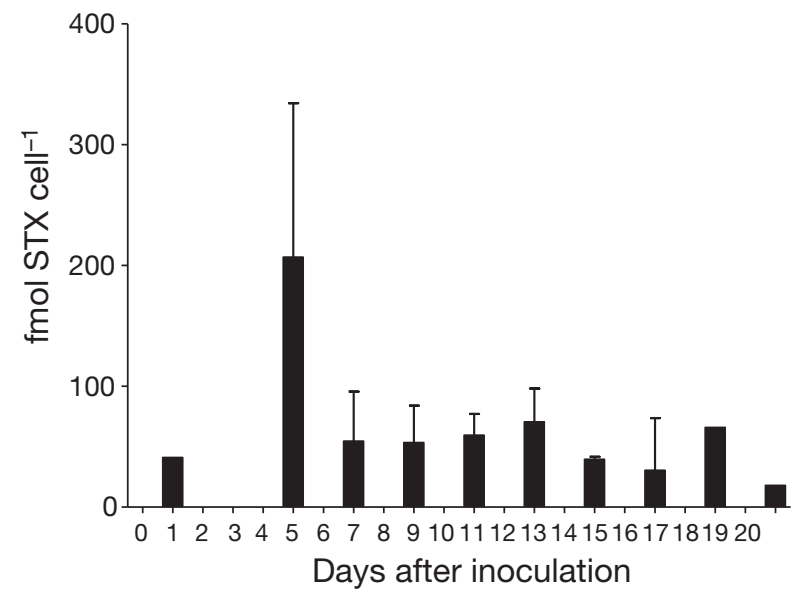

Fig. 1. Nitrogen-limiting saxitoxin (STX) yields per cell in nitrogen-limiting cultures. Values plotted are averages, except for Days 0, 18 and 20, for which only 1 sample was measured. Yields are an indirect estimate based on cell counts and nitrogen yield as measured by isotope ratio mass spectrometry. On Days 4, 8, 10, 12, 14 and 16, $\mathrm{n}=2$; on Day 6, $\mathrm{n}=3$. Error bars represent SD 
Table 1. Nitrate-replete $\delta^{15} \mathrm{~N}$ results and corresponding isotopic differences between medium, whole-cell (WC), and saxitoxin (STX) nitrogen.

\begin{tabular}{|lccc|}
\hline & $\begin{array}{c}\text { Replicates } \\
\text { (n) }\end{array}$ & \multicolumn{2}{c|}{$\delta^{15} \mathrm{~N}(\%)$} \\
& Mean & $\mathrm{SD}$ \\
\hline $\boldsymbol{\delta}^{\mathbf{1 5}} \mathbf{N}$ & & & \\
Medium & 2 & -7.0 & 0.0 \\
WC & 3 & -8.5 & 0.1 \\
STX & 2 & -10.0 & 0.6 \\
Isotopic difference & & \\
Medium-WC & 1.5 & $0.1^{\mathrm{a}}$ \\
WC-STX & 1.5 & $0.6^{\mathrm{a}}$ \\
Medium-STX & 3.0 & $0.6^{\mathrm{a}}$ \\
a Calculated using the equation $\mathrm{S}_{\mathrm{s}}=\sqrt{ }\left(\mathrm{S}_{1}{ }^{2}+\mathrm{S}_{2}{ }^{2}\right)$, in which \\
S $\mathrm{S}_{\mathrm{s}}$ is the standard deviation of the sum, and $\mathrm{S}_{1}$ and $\mathrm{S}_{2}$ are \\
the standard deviations of individual measurements \\
\hline
\end{tabular}

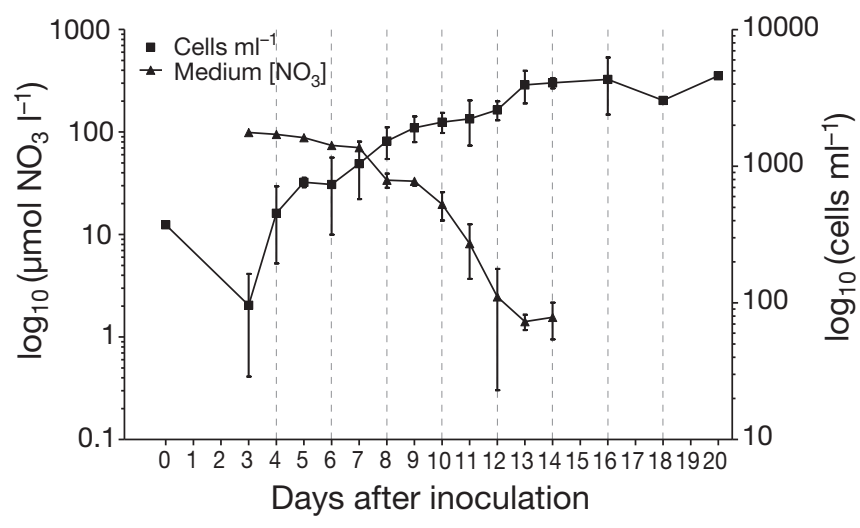

Fig. 2. $\log _{10}$ cells $\mathrm{ml}^{-1}(\mathbf{\Xi})$ and medium nitrate concentrations (₫) over time in nitrogen-limiting cultures. All sample points are averages of triplicate measurements from each of the carboys A, B and C $(\mathrm{n}=6)$, except for cells $\mathrm{ml}^{-1}$ on Days 0,18 and 20, where only 1 culture was measured $(\mathrm{n}=3)$. Error bars represent SD. Dotted vertical lines correspond to samples for isotope measurements

nitrate was first measured on Day 4, at a concentration of $99 \mu \mathrm{mol} \mathrm{l}^{-1}$. Based on mass balance of new $88.3 \mu \mathrm{mol} \mathrm{l}^{-1}$ medium nitrate plus added inoculum nitrate (taking into account nitrate utilization by cells), the starting nitrate concentration on Day 0 was estimated to be approx. $106 \mu \mathrm{mol} \mathrm{l}^{-1}$. Medium nitrate concentrations decreased by $9 \mu \mathrm{mol} \mathrm{l}^{-1} \mathrm{~d}^{-1}$ until nitrate was below detection limits on Day 12 (Fig. 2).

Inoculum nitrate stock $\delta^{15} \mathrm{~N}$ was $-7.0 \pm 0.01 \%$ o $(\mathrm{n}=$ $3)$, whereas new nitrogen-limiting medium was made using nitrate stock with $\delta^{15} \mathrm{~N}$ of $-1.8 \pm 0.05 \%$ $(\mathrm{n}=3)$. As a result of nitrate nitrogen brought in with the inoculum, combined with freshly prepared medium nitrate, the initial $\delta^{15} \mathrm{~N}$ of medium nitrate on Day 0, calculated by mass balance, was $-2.8 \%$ (Fig. 3). Medium nitrate $\delta^{15} \mathrm{~N}$ initially increased

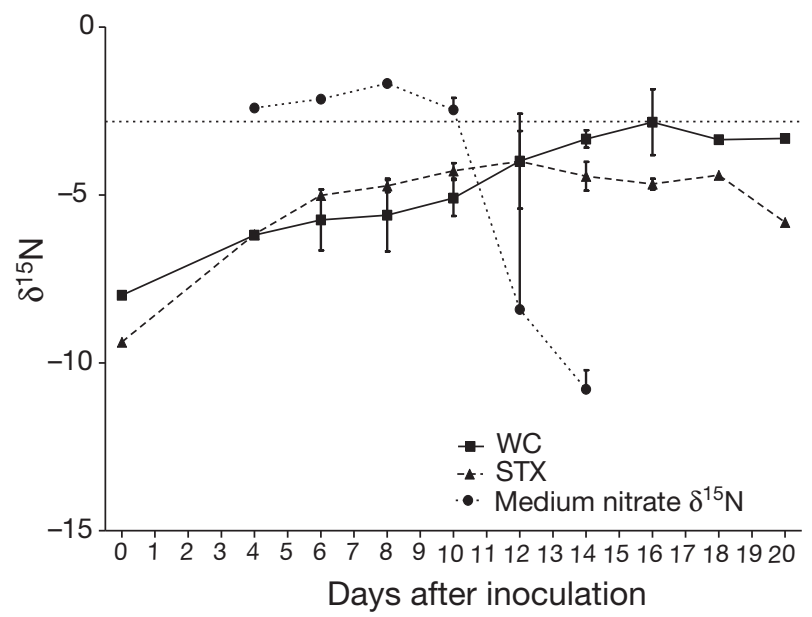

Fig. 3. Average $\delta^{15} \mathrm{~N}$ values of medium nitrate (•), whole-cell $(\mathrm{WC}, \bullet)$ and saxitoxin (STX) $(\boldsymbol{\bullet})$ nitrogen of nitrogen-limiting cultures over time. The dotted horizontal line corresponds to calculated new medium nitrate $\delta^{15} \mathrm{~N}$ of $-2.8 \%$ (based on mass balance between fresh culture medium and inoculum). See Table 2 for number of replicates. Error bars represent SD

between Days 4 and 8, but then decreased between Days 8 (approx. $30 \mu \mathrm{mol} \mathrm{l^{-1 }}$ nitrate) and 12 (nitrate below detection). Whole-cell $\delta^{15} \mathrm{~N}$ increased from $-8.0 \%$ to a high of $-2.8 \%$, and STX $\delta^{15} \mathrm{~N}$ from $-9.4 \%$ to a high of $-4.0 \%$ o (Fig. 3). STX $\delta^{15} \mathrm{~N}$ increased more rapidly than whole-cell $\delta^{15} \mathrm{~N}$ after inoculation, with STX becoming isotopically indistinguishable from whole cells between Days 4 and 12 (Fig. 3), corresponding to when medium nitrate was depleted (Fig. 2). Whole-cell and STX $\delta^{15} \mathrm{~N}$ both increased significantly between Days 0 and 6 (paired $t$-test, $\mathrm{p}<0.05)$.

The \%o difference between medium nitrate and whole cells, and between whole cells and STX, changed over the course of the experiment. The greatest differences between whole-cell nitrogen and STX nitrogen occurred after the medium nitrate had been depleted on Day 12. Isotopic differences between medium nitrate and whole cells ranged from 1.1 up to $5.2 \%$, whole cells and STX from 0.0 up to $2.5 \%$, and medium and STX from 0.2 up to $6.6 \%$ (Table 2). Whole cells maintained an average C:N ratio of $5.4 \pm 0.4$ until Day 12, when medium nitrate was depleted, after which the ratio increased to over 7 (Table 2).

\section{DISCUSSION}

These results provide the first measurements of the isotopic fractionation between STX and the nitrogen source used for cell growth. In addition, they high- 
Table 2. $\delta^{15} \mathrm{~N}$ values, isotopic differences between medium, whole-cell (WC) and saxitoxin (STX) nitrogen, and C:N ratios of nitrogen-limiting cultures over time

\begin{tabular}{|c|c|c|c|c|c|c|c|c|c|}
\hline \multirow{2}{*}{$\begin{array}{l}\text { Days after } \\
\text { inoculation }\end{array}$} & \multicolumn{4}{|c|}{$-\delta^{15} \mathrm{~N}$} & \multicolumn{3}{|c|}{ Isotopic difference } & \multirow[t]{2}{*}{ WC C:N } & \multirow[t]{2}{*}{$\mathrm{n}^{\mathrm{c}}$} \\
\hline & Medium $^{\mathrm{b}}$ & $\mathrm{n}$ & WC & STX & Medium-WC & Medium-STX & WC-STX & & \\
\hline 0 & & & $-7.4 \pm 0.8$ & $-9.4 \pm 0.0$ & $5.2 \pm 0.0^{\mathrm{d}}$ & $6.6 \pm 0.0$ & & $4.7 \pm 1.4$ & 3 \\
\hline 4 & $-2.4 \pm 0.1$ & 4 & $-6.2 \pm 0.1$ & $-6.2 \pm 0.0$ & $3.8 \pm 0.0$ & $3.8 \pm 0.0$ & $0.0 \pm 0.0$ & $5.6 \pm 0.5$ & 2 \\
\hline 6 & $-2.1 \pm 0.0$ & 4 & $-5.7 \pm 1.0$ & $-5.0 \pm 0.1$ & $3.4 \pm 1.2$ & $2.9 \pm 0.1$ & $-0.7 \pm 1.0$ & $5.1 \pm 0.4$ & 3 \\
\hline 8 & $-1.7 \pm 0.1$ & 4 & $-5.6 \pm 1.1$ & $-4.7 \pm 0.2$ & $3.9 \pm 1.1$ & $3.0 \pm 0.2$ & $-0.9 \pm 1.3$ & $5.8 \pm 0.4$ & 2 \\
\hline 10 & $-2.5 \pm 0.4$ & 4 & $-5.1 \pm 0.5$ & $-4.3 \pm 0.2$ & $2.6 \pm 0.3$ & $1.8 \pm 0.5$ & $-0.8 \pm 0.8$ & $5.3 \pm 0.4$ & 2 \\
\hline $12^{\mathrm{a}}$ & $-8.4 \pm 5.3$ & 4 & $-4.0 \pm 1.4$ & $-4.0 \pm 0.1$ & 1.1 & 0.2 & $0.0 \pm 1.3$ & $5.6 \pm 0.7$ & 2 \\
\hline $14^{\mathrm{a}}$ & $-10.8 \pm 0.6$ & 4 & $-3.3 \pm 0.3$ & $-4.4 \pm 0.4$ & & & $1.1 \pm 0.2$ & $7.8 \pm 0.8$ & 2 \\
\hline $16^{\mathrm{a}}$ & & & $-2.8 \pm 1.0$ & $-4.7 \pm 0.2$ & & & $1.8 \pm 1.1$ & $8.9 \pm 0.1$ & 2 \\
\hline $18^{\mathrm{a}}$ & & & -3.4 & -4.4 & & & 1.1 & 7.5 & 1 \\
\hline $20^{\mathrm{a}}$ & & & -3.3 & -5.8 & & & 2.5 & 9.5 & 1 \\
\hline \multicolumn{10}{|c|}{$\begin{array}{l}{ }^{a} \text { Medium nitrate below detection limits } \\
{ }^{b} \text { Duplicates were measured from each carboy sampled } \\
{ }^{\mathrm{c}} \text { Number of replicates corresponding to average } \delta^{15} \mathrm{~N} \text { values on left } \\
{ }^{\mathrm{d}} \text { Calculated with estimated starting medium } \delta^{15} \mathrm{~N}\end{array}$} \\
\hline
\end{tabular}

light the complex physiological relationship between STX synthesis and cell growth under changing nitrate concentrations. While this study demonstrates the purification and isotopic analysis of STX, it is only a first step towards the eventual goal of using this method to understand the nutrient sources fueling Alexandrium blooms in the field. Before this technique can be applied to a natural bloom there are many practical and methodological challenges that need to be resolved. For example, care should be taken when considering species producing multiple toxin congeners, and fractionation may be expected to vary slightly depending on growth stage and nutrient status (Anderson et al. 1990, Leong \& Taguchi 2004, Leong et al. 2004).While further investigation and development are needed, the results provide a proof-of-concept for the potential use of $\delta^{15} \mathrm{~N}$ of STX as a tool for understanding the links between nitrogen and Alexandrium blooms.

Our first step in this study was to establish the extent of isotopic fractionation between nitrate, Alexandrium cells, and STX. We expected that Alexandrium cells would be isotopically lighter than the medium nitrate, and our observation of a $1.5 \%$ fractionation between nitrate and whole cells is similar to previous results showing dinoflagellate $\delta^{15} \mathrm{~N}$ depletion of $2.2 \%$ relative to nitrogen source (Montoya \& McCarthy 1995, Needoba et al. 2004). While nitrogen isotopic fractionation from medium nitrate to STX was anticipated, based on previous studies showing that Alexandrium toxins are synthesized from amino acid precursors (Anderson et al. 1990, Shimizu 1993, Kellmann \& Neilan 2007), the extent of fractionation was unknown as we have a limited understanding of the biochemical process of toxin production in dinoflagellates. Further, the relationship between cell growth and STX synthesis is very complex, being linked to growth phase (Taroncher-Oldenburg et al. 1999), growth rate (Proctor et al. 1975, Ogata et al. 1987, Murata et al. 2006), nitrogen and/or phosphorus supply (Anderson et al. 1990, John \& Flynn 2000, Leong et al. 2004, Murata et al. 2006), and N:P ratio (Béchemin et al. 1999, John \& Flynn 2000). STX $\delta^{15} \mathrm{~N}$ values may therefore depend not only on source materials and enzymatic processes but also on cell physiology and ambient conditions. Under conditions of relatively constant nitrate resupply, we found that STX $\delta^{15} \mathrm{~N}$ was depleted by $3 \%$ relative to the medium nitrate. The resulting $1.5 \%$ difference between whole cells and STX is consistent with the toxin being derived from other cellular components, such as amino acids, with the additional fractionation presumably occurring during some of the enzymatic steps required for STX biosynthesis (Shimizu et al. 1984, Shimizu 1993, Kellmann et al. 2008).

The nitrate-replete experiment determined fractionation of cells under relatively constant nitrate supply, while the nitrogen-limiting experiment examined the effects of changes in both the isotopic composition and concentration of nitrate on the $\delta^{15} \mathrm{~N}$ of cells and STX. In a closed system, as nitrate concentrations decrease, the medium nitrate pool should become progressively enriched in ${ }^{15} \mathrm{~N}$ as cells take up lighter nitrogen in greater proportion (Peterson \& Fry 1987, Fry 2006). However, during the nitrogenlimiting experiment, medium nitrate $\delta^{15} \mathrm{~N}$ values decreased unexpectedly (Fig. 3) as medium nitrate was depleted (after Day 8) (Fig. 2). This may be attri- 
buted to isotopically light DON. DON becomes more prominent as the medium nitrate is depleted and is known to contribute significantly to interference during the ammonium diffusion method (Sigman et al. 1997). DON could have been present in the initial medium as well as released by algal and bacterial cells. Algal toxins are known to be leaked or released from cells (Anderson et al. 1990, John \& Flynn 2002). It is possible that STX contributes a portion of the DON ; however, this contribution is not likely to be significant. The release of STX from cells may affect the overall toxin and nitrogen content of cells, but it should not affect isotopic measurements of whole cells or STX.

We expected that the $\delta^{15} \mathrm{~N}$ of both cells and STX would increase as nitrogen in the medium was drawn down, until their $\delta^{15} \mathrm{~N}$ values approached that of the initial nitrate. At first, whole-cell and STX $\delta^{15} \mathrm{~N}$ changed rapidly because the inoculum cells reflected the $\delta^{15} \mathrm{~N}$ of the inoculum culture nitrate $(-7.0 \%)$, whereas the new medium nitrate had a $\delta^{15} \mathrm{~N}$ value of $-1.8 \%$. The cellular nitrogen pool equilibrated with the external nitrogen pool as nitrogen was taken up and incorporated into cell biomass. Whole cell $\delta^{15} \mathrm{~N}$ mirrored the starting medium $\delta^{15} \mathrm{~N}$ once all medium nitrate had been depleted. STX $\delta^{15} \mathrm{~N}$ changed more rapidly than whole-cell nitrogen before equilibrating to the expected $1.5 \%$ difference observed in nitratereplete culture.

Changes in stable nitrogen isotope ratios of whole cells and STX in nitrogen-limiting cultures occurred at different rates, as cells and STX equilibrated with the new nitrogen source at different times. The STX pool nearly equilibrated within $6 \mathrm{~d}$ (fully equilibrated after $12 \mathrm{~d}$ ) of inoculation whereas whole cells did not equilibrate until 14 to $16 \mathrm{~d}$ (Fig. 3). Faster STX equilibration could be due to the toxin pool increasing faster than the overall cellular $\mathrm{N}$ pool. Changes in STX yield clearly demonstrated that STX is rapidly synthesized from newly incorporated nitrogen as growth resumes nearly simultaneously with nitrate uptake. This peak in STX synthesis on Day 4 (Fig. 1) is reflected in the rapid equilibration of STX $\delta^{15} \mathrm{~N}$ with that of new medium nitrate (Fig. 3). The STX yield returned to a lower, more consistent, value after the initial peak on Day 4.

Several studies have demonstrated that toxin synthesis is faster in early growth phase (given sufficient nutrients) and that the synthesis rate can be higher than growth rate such that the cell content of PST increases even during exponential growth (Anderson et al. 1990, Flynn et al. 1994, John \& Flynn 2000, Grzebyk et al. 2003). Flynn et al. (1994) observed a similar rapid increase in toxin synthesis in Alexandrium minutum when $\mathrm{N}$-starved cells were resupplied with nitrogen. In our experiment, however, the situation was almost the reverse: inoculum cells were growing exponentially in $\mathrm{f} / 2$ medium $\left(883 \mu \mathrm{mol} \mathrm{l}^{-1}\right.$ starting nitrate) before transfer into medium containing $88.3 \mu \mathrm{mol} \mathrm{l}^{-1}$ nitrate. Residual nitrate in the inoculum was estimated to be several hundred $\mu \mathrm{mol}$ $1^{-1}$.This suggests that additional limiting factors, in the presence of available nitrogen, may induce net toxin synthesis in Alexandrium. Indeed, John \& Flynn (2000) suggested either an 'upshock' effect, in which recovery from some type of nutrient stress upon inoculation into new medium may increase toxin production, or conversely, a 'downshock' effect, depending on the metabolic imbalance.

Our data indicate that STX could serve as a species-specific tracer for the nitrogen source used for the growth of Alexandrium. The results of the nitrate-replete culture and nitrogen-limiting timecourse experiments described here show how the $\delta^{15} \mathrm{~N}$ of STX responds to changes in the isotopic composition and concentration of supplied nitrate. The nitrate-replete culture could be compared to an area that receives a relatively constant supply of nitrogen from a consistent source, e.g. groundwater inputs to an embayment or riverine inputs to an estuary under base flow conditions. In this scenario we would expect that-because the nitrogen supply and isotopic composition is relatively invariant - the algal cells would be in equilibrium with the nitrogen source, and STX $\delta^{15} \mathrm{~N}$ would therefore be approx. $3 \%$ below that of the source. These results could be complicated in natural settings by multiple forms of nutrient and sources of varying isotopic ratios to account for. The nitrogen-limiting culture is analogous to a situation of pulsed nutrient supply, such as waste overflow or increased terrestrial runoff from storms, which is likely to have a different nitrogen isotopic composition. After experiencing a pulse of nitrogen with a different $\delta^{15} \mathrm{~N}$, the algal cells will equilibrate with this 'new' source. Because STX equilibrates much faster than the whole cells during this time, STX provides a better marker for nitrogen source during non-steady-state conditions compared with the bulk cells.

While this study provides proof-of-concept for the use of $\delta^{15} \mathrm{~N}$-STX as a species-specific marker of possible nitrogen source (e.g. groundwater, runoff, rainwater) or form (e.g. nitrate, ammonium, urea), additional studies are needed before it can be effectively used in natural waters. Previous studies have shown that Alexandrium is capable of using other 
forms of nitrogen, such as ammonium (Leong et al. 2004), urea (Dyhrman \& Anderson 2003), and amino acids (John \& Flynn 1999), in addition to nitrate. It will be important to establish the fractionation between STX and these other nitrogen forms in order to interpret any field measurements. This study used a strain of Alexandrium that produces 1 toxin congener, STX, almost exclusively. In practice, strains and populations of Alexandrium produce a variety of paralytic shellfish toxins, in varying proportions. The analysis of only 1 toxin (e.g. STX) would greatly reduce the yield of toxin and make the method impractical for field samples. Thus, the method should be extended to include other toxins either by isolating or pooling different toxin congeners. Lastly, to determine accurately the nitrogen source used for growth, it is important to determine not only the $\delta^{15} \mathrm{~N}$ of STX, but also the $\delta^{15} \mathrm{~N}$ of different dissolved nitrogen compounds in the surrounding seawater as the isotopic ratio of the cells will depend upon the isotopic ratio of the nitrogen used for growth. Well-established methods exist for the analysis of $\delta^{15} \mathrm{~N}$ of nitrate (Sigman et al. 1997) and ammonium (Holmes et al. 1998). In contrast, methods for measuring the isotopic composition of dissolved organic nitrogen compounds, such as urea and amino acids, are more complicated and less routine.

This study represents a step forward in our ability to determine the nitrogenous nutrient sources fueling toxin-producing Alexandrium blooms, and the results have implications for our understanding of bloom dynamics and mitigation. In a time when both the frequency and extent of HABs are increasing, with the increase often attributed to anthropogenic nutrient loading (Anderson et al. 2002), knowledge of the form and source of nitrogen supporting a bloom would greatly aid efforts at mitigation. Previous studies (e.g. Leong et al. 2004) have shown that the form of nitrogen used for growth can influence the content of cellular toxin. As the availability of different nitrogen compounds may shift for many reasons - seasonally, as a result of weather events, or additions at point sources, or due to uptake by co-occurring species - the ability to determine the nitrogen source used for growth should enhance our overall understanding of the toxicity and dynamics of Alexandrium blooms.

Acknowledgements. We thank J. McClelland and T. Pease for their support and guidance during this work and also for generously sharing their laboratory facilities and equipment. We also thank P. Garlough for her assistance and for processing all of our isotope samples.

\section{LITERATURE CITED}

Anderson DM, Kulis DM, Sullivan JJ, Hall S, Lee C (1990) Dynamics and physiology of saxitoxin production by the dinoflagellates Alexandrium spp. Mar Biol 104:511-524

Anderson DM, Glibert PM, Burkholder JM (2002) Harmful algal blooms and eutrophication: nutrient sources, composition, and consequences. Estuaries 25(4b):704-726

Béchemin C, Grzebyk D, Hachame F, Hummert C, Maestrini SY (1999) Effect of different nitrogen/phosphorus nutrient ratios on the toxin content in Alexandrium minutum. Aquat Microb Ecol 20:157-165

Boyer GL, Sullivan JJ, Andersen RJ, Harrison PJ, Taylor FJR (1987) Effects of nutrient limitation on toxin production and composition in the marine dinoflagellate Protogonyaulax tamarensis. Mar Biol 96:123-128

Buckley LJ, Ikawa M, Sasner JJ (1976) Isolation of Gonyaulax tamarensis toxins from soft shell clams (Mya arenaria) and a thin-layer chromatographic-fluorometric method for their detection. J Agric Food Chem 24: $107-111$

> Dyhrman ST, Anderson DM (2003) Urease activity in cultures and field populations of the toxic dinoflagellate Alexandrium. Limnol Oceanogr 48:647-655

> Flynn K, Franco JM, Fernández P, Reguera B, Zapata M, Wood G, Flynn KJ (1994) Changes in toxin content, biomass and pigments of the dinoflagellate Alexandrium minutum during nitrogen refeeding and growth into nitrogen and phosphorus stress. Mar Ecol Prog Ser 111: 99-109

Fry B (2006) Stable isotope ecology. Springer, New York, NY, p 194-276

> Gannes LZ, Martinez del Rio C, Koch P (1998) Natural abundance variations in stable isotopes and their potential uses in animal physiological ecology. Comp Biochem Physiol A Mol Integr Physiol 119:725-737

GEOHAB (2006) Global ecology and oceanography of harmful algal blooms, harmful algal blooms in eutrophic systems. Glibert P (ed) IOC and SCOR, Paris and Baltimore

> Grzebyk D, Béchemin C, Ward CJ, Vérité C, Codd GA, Maestrini SY (2003) Effects of salinity and two coastal waters on the growth and toxin content of the dinoflagellate Alexandrium minutum. J Plankton Res 25: 1185-1199

Guillard RRL (1975) Culture of marine invertebrate animals. In: Smith WL, Chanley MH (eds) Culture of marine invertebrates. Plenum, New York, NY, p 29-60

> Hallegraeff GM (1993) A review of harmful algal blooms and their apparent global increase. Phycologia 32:79-99

> Hattenrath TK, Anderson DM, Gobler CJ (2010) The influence of anthropogenic nitrogen loading and meteorological conditions on the dynamics and toxicity of Alexandrium fundyense blooms in a New York (USA) estuary. Harmful Algae 9:402-412

> Holmes RM, McClelland JW, Sigman DM, Fry B, Peterson BJ (1998) Measuring ${ }^{15} \mathrm{~N}-\mathrm{NH}_{4}{ }^{+}$in marine, estuarine, and fresh waters: an adaptation of the ammonium diffusion method for samples with low ammonium concentrations. Mar Chem 60:235-243

> Jaime E, Hummert C, Hess P, Luckas B (2001) Determination of paralytic shellfish poisoning toxins by highperformance ion-exchange chromatography. J Chromatogr A 929:43-49

John EH, Flynn KJ (1999) Amino acid uptake by the toxic dinoflagellate Alexandrium fundyense. Mar Biol 133: 
$11-19$

John EH, Flynn KJ (2000) Growth dynamics and toxicity of Alexandrium fundyense (Dinophyceae): the effect of changing $\mathrm{N}: \mathrm{P}$ supply ratios on internal toxin and nutrient levels. Eur J Phycol 35:11-23

John EH, Flynn KJ (2002) Modelling changes in paralytic shellfish toxin content of dinoflagellates in response to nitrogen and phosphorus supply. Mar Ecol Prog Ser 225: $147-160$

> Jones MN (1984) Nitrate reduction by shaking with cadmium: alternative to cadmium columns. Water Res 18 : 643-646

Kellmann R, Neilan BA (2007) Biochemical characterization of paralytic shellfish toxin biosynthesis in vitro. J Phycol 43:497-508

Kellmann R, Mihali TK, Jeon YJ, Pickford R, Pomati F, Neilan BA (2008) Biosynthetic intermediate analysis and functional homology reveal a saxitoxin gene cluster in cyanobacteria. Appl Environ Microbiol 74:4044-4053

Laycock MV, Thibault P, Ayar SW, Walter JA (1994) Isolation and purification procedures for the preparation of paralytic shellfish poisoning toxin standards. Nat Toxins 2:175-183

Leong SCY, Taguchi S (2004) Response of the dinoflagellate Alexandrium tamarense to a range of nitrogen sources and concentrations: growth rate, chemical carbon and nitrogen, and pigments. Hydrobiologia 515:214-224

Leong SCY, Murata A, Nagashima Y, Taguchi S (2004) Variability in toxicity of the dinoflagellate Alexandrium tamarense in response to different nitrogen sources and concentrations. Toxicon 43:407-415

Lilly EL, Halanych KM, Anderson DM (2007) Species boundaries and global biogeography of the Alexandrium tamarense complex (Dinophyceae). J Phycol 43:1329-1338

McClelland JW, Montoya JP (2002) Trophic relationships and the nitrogen isotopic composition of amino acids in plankton. Ecology 83:2173-2180

Minagawa M, Wada E (1984) Stepwise enrichment of ${ }^{15} \mathrm{~N}$ along food chains: further evidence and the relation between $\delta^{15} \mathrm{~N}$ and animal age. Geochim Cosmochim Acta 48:1135-1140

Montoya JP, McCarthy JJ (1995) Isotopic fractionation during nitrate uptake by phytoplankton grown in continuous culture. J Plankton Res 17:439-464

Murata A, Leong SCY, Nagashima Y, Taguchi S (2006) Nitrogen:phosphorus supply ratio may control the protein and total toxin of dinoflagellate Alexandrium

Editorial responsibility: Matthias Seaman,

Oldendorf/Luhe, Germany tamarense. Toxicon 48:683-689

Needoba JA, Sigman DM, Harrison PJ (2004) The mechanism of isotope fractionation during algal nitrate assimilation as illuminated by the ${ }^{15} \mathrm{~N} /{ }^{14} \mathrm{~N}$ of intracellular nitrate. J Phycol 40:517-522

Ogata T, Kodama M, Ishimaru T (1987) Toxin production in the dinoflagellate Protogonyaulax tamarensis. Toxicon 25:923-928

> Paerl HW (1997) Coastal eutrophication and harmful algal blooms: Importance of atmospheric deposition and groundwater as 'new' nitrogen and other nutrient sources. Limnol Oceanogr 42:1154-1165

Peterson BJ, Fry B (1987) Stable isotopes in ecosystem studies. Annu Rev Ecol Syst 18:293-320

> Proctor NH, Chan SL, Trevor AJ (1975) Production of saxitoxin by cultures of Gonyaulax catenella. Toxicon 13:1-9

Scholin CA, Anderson DA (1993) Population analysis of toxic and non-toxic Alexandrium species using ribosomal RNA signature sequences. In: Smayda TJ, Shimizu T (eds) Toxic phytoplankton blooms in the sea: proceedings of the 5th international conference on toxic marine phytoplankton. Elsevier, New York, NY, p 95-102

Shimizu Y (1993) Microalgal metabolites. Chem Rev 93: 1685-1698

Shimizu Y, Norte M, Hori A, Genenah A, Kobayashi M (1984) Biosynthesis of saxitoxin analogues: the unexpected pathway. J Am Chem Soc 106:6433-6434

Shumway SE (1990) A review of the effects of HABs on shellfish and aquaculture. J World Aquacult Soc 21: 65-104

Sigman DM, Altabet MA, Michener R, McCorkle DC, Fry B, Holmes RM (1997) Natural abundance-level measurement of the nitrogen isotopic composition of oceanic nitrate: an adaptation of the ammonia diffusion method. Mar Chem 57:227-242

Smayda TJ (1990) Novel and nuisance phytoplankton blooms in the sea: evidence for a global epidemic. In: Granéli E, Sundstr m B, Edler L, Anderson DM (eds) Toxic marine phytoplankton: proceedings of the 4th international conference on toxic marine phytoplankton. Elsevier, New York, NY, p 29-40

Taroncher-Oldenburg G, Kulis DM, Anderson DA (1999) Coupling of saxitoxin biosynthesis to the G1 phase of the cell cycle in the dinoflagellate Alexandrin fundyense: temperature and nutrient effects. Nat Toxins 7:207-219

> Wang DZ (2008) Neurotoxins from marine dinoflagellates: a brief review. Marine Drugs 6:349-371

Submitted: February 14, 2011; Accepted: August 23, 2011 Proofs received from author(s): November 30, 2011 